IRA-International Journal of Applied Sciences ISSN 2455-4499; Vol.05, Issue 01 (2016)

Institute of Research Advances

Pg. no. 34-39

http://research-advances.org/index.php/IRAJAS

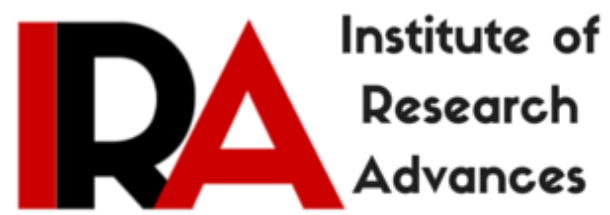

\title{
Considerable Recovery Effect Of EPL And Ashwagandha On The Weight Of Dams And Foetal Weight In Swiss Albino Mice Due To Intoxication Of Mercuric Chloride
}

\author{
Dr. Vishwas Tiwari \\ Astt. Professor \\ Govt. Girls Degree College \\ Dewas ,(M.P.) India.
}

Type of Review: Peer Reviewed.

DOI: http://dx.doi.org/10.21013/jas.v5.n1.p6

\section{How to cite this paper:}

Tiwari, V. (2016). Considerable Recovery Effect Of EPL And Ashwagandha On The Weight Of Dams And Foetal Weight In Swiss Albino Mice Due To Intoxication Of Mercuric Chloride. IRA-International Journal of Applied Sciences (ISSN 2455-4499), 5(1), 34-39. doi:http://dx.doi.org/10.21013/jas.v5.n1.p6

(C) Institute of Research Advances

\section{(cc) BY-NC}

This work is licensed under a Creative Commons Attribution-Non Commercial 4.0 International License subject to proper citation to the publication source of the work.

Disclaimer: The scholarly papers as reviewed and published by the Institute of Research Advances (IRA) are the views and opinions of their respective authors and are not the views or opinions of the IRA. The IRA disclaims of any harm or loss caused due to the published content to any party. 


\begin{abstract}
Investigations were furnished on the toxic effect of mercuric chloride in foetal weights and weight of dam in mice with remarkable recovery effect of Withania somnifera (Ashwagandha) and Essentiale phospholipids (EPL) were observed. Withania somnifera is popularly known as Indian Ginseng and its withanoid content improves the greater gain in body weight, whereas dilinoleoylphosphatidylcholine content of EPL revealed high affinity with lipid contents of blood which consequently increased adipose tissues of body.

The animals were treated with 0.5 ppm aqueous mercuric chloride for a period of 7, 14 and 21 days. For the recovery $175 \mathrm{mg}$ of EPL and $35 \mathrm{mg}$ of ashwagandha were administered to mice (already treated with $\mathrm{HgCl}_{2}$ ) for a period of 7, 14 and 21 days. Daily treatment of $\mathrm{HgCl}_{2}$ for 7,14 and 21 days decreased weight of foetuses and dams. Simultaneous administration of EPL and ashwagandha significantly recovered the weight of foetuses and dams. It appears that the protective effects of EPL and ashwagandha against $\mathrm{HgCl}_{2}$ induced weight alteration is mediated through antioxidative action of EPL and ashwagandha.
\end{abstract}

Key Words : Dams, Foetus, Essentiale Phospholipids, Withania somnifera, Indian Ginseng.

\title{
Introduction
}

. The chelate binding character of metals with various chelating agents like EPL, Ashwagandha, EDTA, Tiron, DTPA etc., were the key aspect of the recovery of metal intoxication in mice. On the other hand, Domingo et al. $(1990 ; 1992)$ investigated effectiveness of chelation therapy with time after acute uranium intoxication in mice while James and Soni (1991) observed changes in tissue proteins due to administration of $\mathrm{HgCl}_{2}$ and two chelators in mice. The present research was aimed to investigate the embryofoetotoxicity and teratogenicity of $\mathrm{HgCl}_{2}$ in mice and its detoxification by herbal products i.e. ashwagandha and EPL. . Mercuric chloride is cumulative poison and considered as direct acting toxicant. Goodman (1983) observed mercuric chloride toxicity on placenta of female rats, while Marszalek (1984) investigated mercuric chloride toxicity on foetus of female rats. The toxicity and teratogenicity of uranium is noteworthy aspect in the field of reproductive toxicology, the oral administration of uranium was thoroughly studied by many authors. Domingo (2001) investigated reproductive and teratogenetic aspects of natural and depleted uranium in mice. Benson and McBride (1997) observed uranium concentration in the foetus and placenta of female rats. Bosque et al. (2001) observed various aspects of reproductive and developmental toxicity of natural and depleted uranium in mice.

Teratological investigations emphasizes that the intoxication of mercuric chloride causes drastic environmental contamination and severe effects on the reproductive tissues of the mice.According to evidences in the field of teratology the toxicity of heavy metal and their compounds causes lethal effect on the reproductive processes and fertility including teratogenicity and embryofoetotoxicity in pregnant animals.

\section{Materials and Methods}

Experimental animals - Eighty four young isogenic healthy sexually mature Swiss albino mice (weighing $24 \pm \mathrm{gm}$ ) were used for present study. The mice were procured from Veterinary College, Mhow (M.P.). They were fed with balanced standard food of mice consisting of wheat $19.7 \%$, maize $29.50 \%$, gram $19.7 \%$, barley $29.5 \%, \mathrm{NaCl} 0.5$ gms, groundnut oil $0.99 \%$ and water ad-libitum daily.

Exposure of mice to mercury - The animal were treated with $0.5 \mathrm{ml} / \mathrm{day}$ of $0.5 \mathrm{ppm}$ aqueous $\mathrm{HgCl}_{2}$ for a period of 7, 14 and 21 days. 
Chemicals and herbal compounds - Mercury ( $\mathrm{Hg}$ ) was used as $\mathrm{HgCl}_{2}$ marketed by Qualigens fine chemicals (A division of Glaxo India Ltd.). In the present study the drug 'Essentiale' manufactured by Nattermann International GMBH, West Germany and ashwagandha manufactured by the Dabur India Ltd., were used as detoxifying agent.

Determination of dose : The dose of $0.5 \mathrm{ml} \mathrm{HgCl} 2$ solution determined by LC $50 \%$ mortality method, while the dose of 'Essentiale' were directly used as a capsule of $175 \mathrm{mg}$ standard quantity manufactured by Nattermann International GMBH Company, West Germany and $35 \mathrm{mg}$ dose of Ashwagandha was used, which was earlier found most effective Panda et al. (1997).

Experimental design - A total number of 84 pregnant mice were divided in three groups.

Group I : 21 mice in this group (7 in each cage) were given standard food and plain water.

\section{Group II : Experimental group}

Cage $1-7$ mice were kept in the cage and were given standard food + water $+0.5 \mathrm{ml} \mathrm{HgCl}_{2}$ solution were administered orally through blunt needle into mouth cavity of the female mice for 7 days.

Cage $2-7$ mice were kept in the cage and were given standard food + water $+0.5 \mathrm{ml} \mathrm{HgCl}_{2}$ solution for 14 days.

Cage 3- 7 mice were kept in the cage and were given standard food + water $+0.5 \mathrm{ml} \mathrm{HgCl}_{2}$ solution for 21 days.

\section{Group III : Recovery group}

Cage $1-7$ mice were kept in the cage treated with $\mathrm{HgCl}_{2}(0.5 \mathrm{ml})$ after 21 days were given food and water and $175 \mathrm{mg}$. Essentiale were mixed with food to mice for 7 days.

Cage 2 - 7 mice were kept in the cage treated with $\mathrm{HgCl}_{2}(0.5 \mathrm{ml})$ after 21 days were given food and water and $35 \mathrm{mg}$. ashwagandha were mixed with food to mice for 7 days.

Cage 3 - 7 mice were kept in the cage treated with $\mathrm{HgCl}_{2}(0.5 \mathrm{ml})$ after 21 days were given food and water and $175 \mathrm{mg}$. Essentiale were mixed with food to mice for 14 days.

Cage 4 - 7 mice were kept in the cage treated with $\mathrm{HgCl}_{2}(0.5 \mathrm{ml})$ after 21 days were given food and water and $35 \mathrm{mg}$. ashwagandha were mixed with food to mice for 14 days.

Cage 5 - 7 mice were kept in the cage treated with $\mathrm{HgCl}_{2}(0.5 \mathrm{ml})$ after 21 days were given food and water and $175 \mathrm{mg}$. Essentiale were mixed with food to mice for 21 days.

Cage 6 - 7 mice were kept in the cage treated with $\mathrm{HgCl}_{2}(0.5 \mathrm{ml})$ after 21 days were given food and water and $35 \mathrm{mg}$. ashwagandha were mixed with food to mice for 21 days.

The mice of experimental group I, II and III were sacrificed in 7, 14 and 21 days and along with them the animal of control group were sacrificed on the same day.

\section{Embryofoetotoxicity Study :}

The pregnant mice were anaesthetized by diethyl ether. The abdomens were incised longitudinally and both uterine horns were carefully exposed. The position and number of live and dead foetuses were recorded for each dam. Individual foetal weights were recorded. Foetuses were carefully examined for external abnormalities. Half of the foetuses were fixed in aqueous Bouin's solution and half in $10 \%$ formalin solution.

\section{Results and Discussion}

After the treatment with $0.5 \mathrm{ml} \mathrm{HgCl}_{2}$ and recovery by $175 \mathrm{mg}$. EPL and $35 \mathrm{mg}$ Ashwagandha, the pregnant mice revealed remarkable changes in foetal weight (Table 1). The number of live and dead foetuses were recorded for each dam, significant alteration in foetuses weight were observed in each litter. Many workers observed the effects of heavy metals and other toxic substances on maternal and foetal body weight. Ahmed and Gupta (1986) studied reproductive toxicity of cypermethrin in rats, they 
observed remarkable alteration in foetal weight due to intoxication while Shrivastava et al. (1990) studied exposure of styrene in rats leads to embryofoetotoxicity and alteration in maternal and foetal body weight. Similarly Marszalek (1984) observed $\mathrm{HgCl}_{2}$ toxicity on pregnant female rats and foetus, while Sehgal et al. (1995) seen teratogenic effect of lead in mice. In the present experiment, the effect of $\mathrm{HgCl}_{2}$ on maternal and foetal body weight in control, treated and recovery group were observed in 6-15 days of gestation period. In 7 days treated group with comparison to control group the decrease of average $4 \mathrm{mg}$ foetal weight were recorded, while in 14 days treated group the decrease of at least $7 \mathrm{mg}$ foetal weigh observed. In 21 days treated group a significant decrease in foetal weight were observed i.e. alteration of al least 7 to $10 \mathrm{mg}$ in average in each litters (Table 1). The decrease in foetal weight may be due to insufficient supply of nourishment from placenta to foetus through umbilical cord because of $\mathrm{HgCl}_{2}$ intoxication. Recovery agent EPL is known to increase lipid contents of body of animal. Kuntz (1990) while assessing the research of 50 years on EPL was investigated that dilinoleoyphosphatidylcholine in EPL contains polyunsaturated fatty acids which facilitate lipid content transport across the membrane of tissues, thus increasing cholesterol content in body, consequently increased the maternal and foetal weight. In the present experiment with comparison to treated group the considerable increase in foetal weight were observed. In 7, 14 and 21 days of recovery groups of pregnant mice the average increase of 5 to $7 \mathrm{mg}$ foetal weight were recorded (Table 2). It may be due to synergistic action of EPL with $\mathrm{HgCl}_{2}$. Ashwagandha is considered as esteemed rasayana drug and used as recovery agent in ayurvedic medicine exhibit antagonistic effect against $\mathrm{HgCl}_{2}$. The amelioration and prevention of reproductive organs with heavy metal toxicity in mammals by chelation therapy has been the basis for the medical treatment of metal poisoning from last five decades. The natural ayurvedic recovery agent ashwagandha is markedly effective in chelation therapy, while Withania somnifera or ashwagandha is popularly known as the Indian Ginseng has been used for a very long time even during pregnancy to improve the maternal and foetal health (Sharma et al., 1985). Patwardhan et al. (1988), Sharma and Dandiya (1991) observed comparative effect of Korean Ginseng and Withania somnifera that, withanoid content of Withania remarkably increased body weight of animal instead of Korean Ginseng. In our experiment, a considerable increase in maternal and foetal body weight were observed in all 7, 14 and 21 day of ashwagandha treated groups i.e. average increase of 10 to $15 \mathrm{mg}$ foetal/maternal weight were observed (Tables 2 and 3).

In 7 days experiments at least $6 \mathrm{~g}$ decrease in body weight of dams were observed in treated group than control group and EPL showed significant increase of $7 \mathrm{~g}$ weight as compared to ashwagandha group, which revealed $5 \mathrm{~g}$ increase in weight (Table 3 ).

In 14 days experiment $4 \mathrm{~g}$ weight of mice increased in control group due to continuous nutrient and water supply. Treated group showed decrease of $6 \mathrm{~g}$ weight, while EPL recovery group showed increase of $7 \mathrm{~g}$ weight and ashwagandha recovery group revealed increase of $5 \mathrm{~g}$ weight (Table 3 ).

In 21 days experiment again weight of dams increased in control group due to continuous nutritious food and water supply. Treated group showed significant decrease of $8 \mathrm{~g}$ weight of dams. In EPL recovery group tremendous increase of $7 \mathrm{~g}$ weight were observed while ashwagandha group revealed increase of at least $5 \mathrm{~g}$ weight (Table 3).

On the basis of these observations it is clearly indicated that $\mathrm{HgCl}_{2}$ significantly altered the weight of dams due to its toxic effect on nutritional metabolism. The EPL recovery group revealed more significant increase in weight of dams than ashwagandha and treated group because of high affinity of phosphatidylcholine to lipid contents of blood, which in turn increased contents of adipose tissues of body. Ashwagandha showed comparatively less effect on weight of dams but revealed significant increase of $5 \mathrm{~g}$ weight of dams than treated group. 
The essentiale phospholipids are successful lipid modulators, it increased fast recovery with lipid contents (cholestrol, ergasterol etc.) of blood consequently adipose tissues revealed more and more deposition of fat which subsequently revealed more weight gain which results increase in weight of the animal. Ashwagandha and EPL both are effective chelating agents and exerts quick, prolonged, protective effect on heavy metal treated intoxicated tissues.

\section{Conclusion}

This study emphasizes an understanding of deterministic investigation applied to the toxic effect of heavy metal mercuric chloride and considerable role of EPL and Withania somnifera in the recovery of foetal weights and weight of dam and absolutely focused on teratological aspects of embryofoetotoxicity and teratogenicity on the pregnant mice (dams). This study also provides the considerable role of EPL and ashwagandha on the intoxication of heavy metals like mercuric chloride on the reproductive tissues of the animals and can be a clue for the reproductive aspects of a pregnant human female as investigations were made on the pregnant swiss albino mice (musculus albinus)

\section{References}

Ahmed N. and Gupta P. K. (1986). Reproductive toxicity of cypermethrin in rats. J. Env. Biol., 9(2) : 149156.

Benson, K. A. and McBride, S. A. (1977). Uranium levels in the foetus and placenta of female rats implanted with depleted uranium pellets prior to breeding. Toxicologist, $\mathbf{3 6}: 258$.

Bosque, M. A.; Domingo, J. L. and Corbella, J. (2001). Embryofoetotoxicity of uranium in mice : variability with the day of exposure. Rev. Toxicol., $9:$ 107-110.

Domingo, J. L. (2001). Reproductive and developmental toxicity of natural and depleted uranium. Report Toxicol., $15: 603-609$.

Domingo, J. L.; Ortega, A.; Llobet, J. M. and Corbella, J. (1990). Effectiveness of chelation therapy with time after acute uranium intoxication. Fundam. Appl. Toxicol., $14: 88-95$.

Domingo, J. L.; Colomina, M. T.; Llobet, J. M.; Jones, M. M.; Singh, P. K. and Campbel, R. A. (1992). The action of chelating agents in experimental uranium intoxication in mice : Variations with structure and time of administration. Fund. Appl. Toxicol., 19: 350-357.

Goodman, D. R. (1983). $\mathrm{HgCl}_{2}$ toxicity on placenta of female rats. Terato. Carcinog. Muta., 3(1) : 89100.

James, A. and Soni V. C. (1991). Changes in tissue proteins due to administration of $\mathrm{HgCl}_{2}$ and two chelators in mice. Com. Physiol. Ecol., 16(1) : 32-37.

Kuntz, E. (1990). 50 years of EPL in hepatology. Kongre. B. actuell., 5 : 1-12.

Marszalek, K. (1984). Effects of $\mathrm{HgCl}_{2}$ on pregnant female rats and foetus. Acta. Boil. Cracov. Ser. Zool., $25: 1-14$.

Patwardhan, S.; Sharma, K. and Dandiya, P. C. (1988). Role of Withania somnifera during pregnancy without toxic effects. National Integrated Medical Association., 30 (6) : 247-250.

Panda, S.; Gupta, P. and Kar, A. (1997). Protective role of ashwagandha in cadmium induced hepatotoxicity and nephrotoxicity in male mouse. Current Science, 72 (8) : 546-547.

Sehgal, S.; Kumar, A. and Kale, R. K. (1995). Teratogenic effects of Cd in Swiss albino mice. J. Env. Pollut., 2 : 13-16.

Sharma, K.; Dandiya, P. C. and Patwardhan, S. (1985). Withania somnifera as the Indian Ginseng, Indian Drugs., 23(3) : 247-250.

Sharma, K. and Dandiya, P. C. (1991). Protective effect of Withania somnifera in pregnancy. Indian Drugs., 29 (6) : 247-250.

Shrivastava, S.; Shrivastava, P. and Seth, P. K. (1990). Embryofoetotoxicity of styrene in rats. J. Environ. Biol., 11(1) : 73-77. 
Table - 1: Illustrating alterations in foetal weight in control and treated groups of dams.

\begin{tabular}{|l|l|c|c|c|r|}
\hline S.No. & \multicolumn{1}{|c|}{ Group of dams } & $\begin{array}{c}\text { Average } \\
\text { foetal weight } \\
\text { in first litter } \\
\mathbf{( 6 F )}(\mathbf{m g .})\end{array}$ & $\begin{array}{c}\text { Average } \\
\text { foetal weight } \\
\text { in second } \\
\text { litter } \mathbf{5} \text { F) } \\
(\mathbf{m g})\end{array}$ & $\begin{array}{c}\text { Average } \\
\text { foetal weight } \\
\text { in third litter } \\
\mathbf{( 7 ~ F ) ~} \\
\mathbf{( m g )}\end{array}$ & $\begin{array}{c}\text { Average } \\
\text { foetal weight } \\
\text { in fourth } \\
\text { litter } \mathbf{6 F}) \\
(\mathbf{m g})\end{array}$ \\
\hline 1. & 7 days control & 78.00 & 80.00 & 82.60 & 84.30 \\
\hline 2. & 7 days treated & 73.60 & 74.20 & 73.80 & 75.70 \\
\hline 3. & 14 days control & 126.00 & 124.60 & 132.80 & 135.20 \\
\hline 4. & 14 days treated & 120.00 & 118.30 & 125.80 & 129.30 \\
\hline 5. & 21 days control & 182.00 & 189.00 & 220.00 & 218.00 \\
\hline 6. & 21 days treated & 177.00 & 183.40 & 213.20 & 212.30 \\
\hline
\end{tabular}

Dams = Pregnant mice

F $=$ Foetus

Table - 2: Illustrating alterations in foetal weight in recovery groups of dams.

\begin{tabular}{|l|l|r|r|r|r|}
\hline $\begin{array}{c}\text { S. } \\
\text { No. }\end{array}$ & \multicolumn{1}{|c|}{ Group of dams } & $\begin{array}{c}\text { Average } \\
\text { foetal weight } \\
\text { in first litter } \\
\mathbf{( 6 F )}(\mathbf{m g})\end{array}$ & $\begin{array}{c}\text { Average } \\
\text { foetal weight } \\
\text { in second } \\
\text { litter } \mathbf{5} \text { F) } \\
(\mathbf{m g})\end{array}$ & $\begin{array}{c}\text { Average } \\
\text { foetal weight } \\
\text { in third litter } \\
\mathbf{( 7 ~ F ) ~} \\
\mathbf{( m g )}\end{array}$ & $\begin{array}{c}\text { Average } \\
\text { foetal weight } \\
\text { in fourth } \\
\text { litter } \mathbf{6 F}) \\
(\mathbf{m g})\end{array}$ \\
\hline 1. & 7 days EPL & 79.00 & 82.00 & 86.20 & 88.30 \\
\hline 2. & 7 days Ashwagandha & 78.30 & 80.20 & 83.90 & 82.40 \\
\hline 3. & 14 days EPL & 127.80 & 130.60 & 132.80 & 134.00 \\
\hline 4. & 14 days Ashwagandha & 128.40 & 133.00 & 134.20 & 130.80 \\
\hline 5. & 21 days EPL & 181.20 & 188.30 & 219.00 & 220.00 \\
\hline 6. & 21 days Ashwagandha & 182.90 & 187.00 & 217.90 & 219.20 \\
\hline
\end{tabular}

Dams = Pregnant mice

F $=$ Foetus

Table - 3: Weight of dams in different groups.

\begin{tabular}{|c|c|c|c|c|c|c|}
\hline $\begin{array}{c}\text { S. } \\
\text { No. }\end{array}$ & Days & $\begin{array}{c}\text { Number of } \\
\text { dams }\end{array}$ & $\begin{array}{c}\text { Control } \\
\text { (gm) }\end{array}$ & $\begin{array}{c}\text { Treated } \\
\text { HgCl }_{\mathbf{2}} \\
\text { (gm) }\end{array}$ & $\begin{array}{c}\text { Recovery I } \\
\text { Ashwagandha } \\
\text { (gm) }\end{array}$ & $\begin{array}{c}\text { Recovery II } \\
\text { EPL (gm) }\end{array}$ \\
\hline & 7 & I & 25.00 & 21.60 & 26.20 & 27.80 \\
1. & & II & 28.00 & 23.20 & 25.00 & 29.30 \\
& & III & 26.00 & 20.80 & 24.20 & 27.30 \\
& & IV & 30.00 & 24.60 & 27.30 & 30.20 \\
& & V & 29.00 & 25.70 & 28.30 & 31.50 \\
\hline & 14 & I & 30.60 & 26.00 & 31.20 & 33.00 \\
& & II & 29.30 & 25.30 & 30.00 & 32.10 \\
& & III & 32.00 & 24.80 & 32.30 & 33.50 \\
& & IV & 33.80 & 25.00 & 32.80 & 34.40 \\
3. & & V & 34.00 & 26.50 & 31.60 & 34.60 \\
\hline & 21 & I & 38.30 & 32.90 & 37.00 & 38.20 \\
& & II & 40.00 & 33.60 & 38.90 & 40.20 \\
& & III & 42.30 & 34.40 & 37.20 & 39.90 \\
& & IV & 43.50 & 35.20 & 38.20 & 39.20 \\
\hline
\end{tabular}

Dams = Pregnant mice. 